\title{
Special Issue of International Journal of Human Resource Management: Conceptual and empirical discoveries in successful HRM implementation
}

\section{Tanya Bondarouk, Jordi Trullen \& Mireia Valverde}

To cite this article: Tanya Bondarouk, Jordi Trullen \& Mireia Valverde (2016) Special Issue of International Journal of Human Resource Management: Conceptual and empirical discoveries in successful HRM implementation, The International Journal of Human Resource Management, 27:8, 906-908, DOI: 10.1080/09585192.2016.1154378

To link to this article: http://dx.doi.org/10.1080/09585192.2016.1154378

Published online: 01 Mar 2016.

Submit your article to this journal $₫$

LII Article views: 149

Q View related articles $\square$

View Crossmark data ¿ 


\title{
CALL FOR PAPERS
}

\section{Special Issue of International Journal of Human Resource Management: Conceptual and empirical discoveries in successful HRM implementation}

\author{
Tanya Bondarouk ${ }^{\mathrm{a} *}$, Jordi Trullen ${ }^{\mathrm{b}}$ and Mireia Valverde ${ }^{\mathrm{c}}$ \\ ${ }^{a}$ Human Resource Management Department, University of Twente, Enschede, The Netherlands; \\ ${ }^{b}$ Department of People Management and Organisation, ESADE Business School, Barcelona, \\ Spain; ${ }^{c}$ Department of Business Management, Universitat Rovira i Virgili (URV), Reus, Spain
}

\section{Background}

As the body of evidence has grown over the years showing a positive association between HRM and firm performance (Becker \& Gerhart, 1996; Boselie, Dietz, \& Boon, 2005; Combs, Liu, Hall, \& Ketchen, 2006), interest has shifted toward understanding how this relationship takes place. Among various approaches, HR scholars have been paying increasing attention to the way in which HRM practices are implemented in organizations. It is argued that successful implementation is a necessary condition for a relationship between HRM and firm performance (Woodrow \& Guest, 2014). The focus of this Special Issue is on implementation of HRM practices, seen as a non-linear process that starts with the design of a new HRM policy and/or practice, and evolves toward its engaged use by employees, managers and HRM professionals. Our purpose is to expand the research field in this area.

Since Bowen and Ostroff (2004) introduced their concept of HRM system strength, scholars have reached a consensus and see HRM implementation as a process. However, precisely what this process comprises is unclear: sometimes, HRM implementation is only seen as the process of translating intended practices into actual practices (Chow, 2012; Khilji \& Wang, 2006; Wright \& Nishii, 2013), while in other contributions, the design phase of HRM practices and policies is also seen as part of HRM implementation (Guest \& Bos-Nehles, 2013; Woodrow \& Guest, 2014). Neither is the end of the process entirely agreed upon; some conceptualize it as when HRM practices are implemented by line managers (Guest \& Bos-Nehles, 2013; Khilji \& Wang, 2006; Wright \& Nishii, 2013), while others end HRM implementation with the experience of HRM by employees (Brewster, Gollan, \& Wright, 2013; Geare, Edgar, \& McAndrew, 2006). The managerial responsibility for HRM implementation also changes with varying perspectives on what HRM implementation comprises and what tasks are not included in the concept. For example, when HRM implementation refers to the translation of intended to actual HR practices, then line managers are the key actors in HRM implementation. However, when viewed as a multi-staged process, other actors may also be included. Finally, when HRM implementation is successful is usually defined

*Corresponding author. Email: t.bondarouk@utwente.nl 
through its effectiveness, but this varies from article to article. Most common definitions are either (1) effective HRM implementation is when implemented practices are equal to intended HR practices (e.g. Woodrow \& Guest, 2014); or (2) effective HRM implementation is the attainment of desired employees' outcomes, such as employee commitment or employee satisfaction with HR practices (e.g. Khilji \& Wang, 2006). In sum, while the topic of HRM implementation has attracted increasing interest in the last decade, it is still a burgeoning research area that holds much promise for future development and consolidation.

Due to such increasing interest, several calls have been made in recent years addressing HRM implementation in one way or another (e.g. 'Comparative Perspectives on HR and Line Manager Relationships and their Effects on Employees' in the International Journal of Human Resource Management, 2011; 'Human Resource Management and the Line' in Human Resource Management, 2013; 'HRM Implementation Effectiveness in Europe' in the European Journal of International Management, forthcoming). Yet, in all instances, the focus of these calls has been primarily on the relationship between line managers and HR professionals. In this Special Issue, we make a call to explore other relevant topics that may have been forgotten. First, we call for contributions that consider more and different actors in HRM implementation apart from HRM professionals and line managers. Second, we call for a broader conceptualization of HRM implementation success that goes beyond its effectiveness. Third, we welcome contributions that attempt to differentiate between successful implementation of HRM and the success of HRM in organizations.

We are particularly interested in studies that offer new theoretical, methodological and empirical insights, contributing HRM in this way to our understanding of a multiactor, multi-level and evolving nature of HRM implementation.

Sample subjects for further examination may include:

- Conceptual clarity and measurement of HRM implementations: What theories are better suited to explain different aspects of HRM implementations and why? Can we generate mid-range theories of implementation? How may different paradigms on theory building (Gioia \& Pitre, 1990) offer diverse perspectives on HRM implementation (e.g. Alvesson \& Kärreman, 2007)? What research designs are better suited to study HRM implementation processes?

- Stakeholder's view of HR implementation: What is the role of top management, consultants, outsourcing vendors, trade unions and employees in HRM implementation? How is effective implementation perceived by different actors and what underlying frames do they use to form their judgments? What interactions among different actors affect HRM implementation success?

- Context in HRM implementation: What are the effects of labor legislations, industrial relations systems, cultural differences, organizational structure and technology on the success of HRM implementations?

- The role of time in HRM implementation: What are the mechanisms and processes that explain improved versus diminished use of HRM policies over time (e.g. Bartunek, Trullen, Immediato, \& Schneider, 2008)?

- HRM implementation and technology: What is the role of information technology in shaping HRM implementation processes? 


\section{Submission guidelines}

Manuscripts should be submitted online using the International Journal of Human Resource Management ScholarOne Manuscripts site (http://mc.manuscriptcentral.com/ Rijh) by December 1, 2016. The Special Issue is scheduled for a publication in 2018.

All manuscripts will be reviewed as a cohort for this Special Issue. All submissions will go through the IJHRM regular double-blind review process and follow the standard norms and processes.

\section{References}

Alvesson, M., \& Kärreman, D. (2007). Unraveling HRM: Identity, ceremony, and control in a management consulting firm. Organization Science, 18, 711-723.

Bartunek, J., Trullen, J., Immediato, S., \& Schneider, F. (2008). Front and backstages of the diminished routinization of innovations: What innovation research makes public and organizational research finds behind the scenes. Strategic Entrepreneurship Journal, 1, 295-314.

Becker, B. E., \& Gerhart, B. (1996). The impact of human resource management on organizational performance: Progress and prospects. Academy of Management Journal, 39, 779-801.

Boselie, P., Dietz, G., \& Boon, C. (2005). Commonalities and contradictions in HRM and performance research. Human Resource Management Journal, 15, 67-94.

Bowen, D. E., \& Ostroff, C. (2004). Understanding HRM-firm performance linkages: The role of "strength" of the HRM system. Academy of Management Review, 29, 203-221.

Brewster, C., Gollan, P. J., \& Wright, P. M. (2013). Guest editors' note: Human resource management and the line. Human Resource Management, 52, 829-838.

Chow, I. (2012). The roles of implementation and organizational culture in the HR-performance link. The International Journal of Human Resource Management, 23, 3114-3132.

Combs, J., Liu, Y., Hall, A., \& Ketchen, D. (2006). How much do high-performance work practices matter? A meta-analysis of their effects on organizational performance. Personnel Psychology, 59, 501-528.

Geare, A., Edgar, F., \& McAndrew, I. (2006). Employment relationships: ideology and HRM practice. The International Journal of Human Resource Management, 17, 1190-1208.

Gioia, D., \& Pitre, E. (1990). Multiparadigm perspectives on theory building. Academy of Management Review, 15, 584-602.

Guest, D. E., \& Bos-Nehles, A. C. (2013). HRM and performance: The role of effective implementation. In J. Paauwe, D. E. Guest, \& P. W. Wright (Eds.), HRM and performance: Achievements and challenges (pp. 79-96). Chichester: Wiley.

Khilji, S. E., \& Wang, X. (2006). 'Intended' and 'implemented' HRM: The missing linchpin in strategic human resource management research. The International Journal of Human Resource Management, 17, 1171-1189.

Woodrow, C., \& Guest, D. E. (2014). When good HR gets bad results: Exploring the challenge of HR implementation in the case of workplace bullying. Human Resource Management Journal, 24, 38-56.

Wright, P. M., \& Nishii, L. H. (2013). Strategic HRM and organizational behaviour: Integrating multiple levels of analysis. In J. Paauwe, D. E. Guest, \& P. M. Wright (Eds.), HRM and performance: Achievements and challenges (pp. 97-111). London: Wiley. 